\title{
SOSIALISASI KEBUTUHAN DIGITAL MARKETING (KONSEP UNTUK UMKM “MARTINI ART" KERAJINAN PAHAT KAYU DESA WANAKERTA)
}

\author{
Syifa Pramudita Faddila ${ }^{1}$, Doni Efendi ${ }^{2}$, Siti Arinka Dwi Sulistia ${ }^{3}$, \\ Muhammad Farhan Reza Pahlevi ${ }^{4}$ \\ Prodi Manajemen, Fakultas Ekonomi dan Bisnis, UBP Karawang ${ }^{1,2}$ \\ syifa.pramudita@ubpkarawang.ac.id,mn17.doniefendi@mhs.ubpkarawang.ac.id, \\ mn17.sitisulistia@mhs.ubpkarawang.ac.id, \\ si17.muhammadpahlevi@mhs.ubpkarawang.ac.id
}

\begin{abstract}
Abstrak
UMKM memiliki kontribusi penting dan strategis dalam meningkatkan perekonomian daerah. Sehingga dianggap perlu melakukan pengembangan digitalisasi marketing dalam melakukan pengelolaan bisnis sebagai upaya dalam mengahadapi persaingan secara global. Desa Wanakerta memiliki UMKM yang dikembangkan oleh masyarakat sendiri yaitu usaha ukiran pahat "Martini Art", namun masih terkendala dengan kurangnya promosi yang dilakukan oleh pemilik maupun oleh pemerintah setempat, terutama minimnya promosi di media sosial ataupun digital marketing. Sosialisasi dilakukan kepada Kepala Desa dan Sekretaris Desa Wanakerta sebagai pemegang kebijakan di wilayah Desa Wanakerta dengan menggunakan metode ceramah, diskusi dan simulasi. Hasil dari kegiatan pkm ini ialah terpenuhinya kebutuhan digital marketing melalui platform Fecabook, Instagram dan Web. Kepala Desa dan Sekretaris Desa Wanakerta pun bersedia untuk melakukan pengembangan dan pemantauan penggunaan emarketing tersebut.
\end{abstract}

Kata kunci: digital marketing, Martini Art, pengabdian masyarakat

\begin{abstract}
UMKM has an important and strategic contribution in improving the regional economy. So it is considered necessary to develop marketing digitalization in managing business as an effort to face global competition. Wanakerta Village has an UMKM developed by the community itself, namely the "Martini Art" carving business, but it is still constrained by the lack of promotion by the owner and the local government, especially the lack of promotion on social media or digital marketing. The socialization was carried out to the Village Head and the Village Secretary of Wanakerta as policy holders in the Wanakerta Village area using lecture, discussion and simulation methods. The result of this PKM activity is the
\end{abstract}


fulfillment of digital marketing needs through the Fecabook, Instagram and Web platforms. The Village Head and the Village Secretary Wanakerta are also willing to develop and monitor the use of e-marketing.

Keywords: digital marketing, Martini Art, community service

\section{PENDAHULUAN}

Saat ini UMKM (Usaha Mikro, Kecil dan Menengah) sedang menjadi pusat perhatian. Hal ini dikarenakan UMKM memiliki kontribusi penting dan strategis dalam meningkatkan perekonomian daerah (Hamid \& Susilo, 2011). Menurut Undang-Undang Nomor 20 Tahun 2008 yang dimaksud dengan UMKM yaitu:

a. Usaha mikro merupakan usaha produktif milik orang perorangan dan/atau badan usaha perorangan yang memiliki kekayaan bersih paling banyak Rp50.000.000 tidak termasuk tanah dan bangunan tempat usaha, atau memiliki hasil penjualan tahunan paling banyak Rp 300.000.000.

b. Usaha kecil merupakan usaha ekonomi produktif yang berdiri sendiri, yang dilakukan oleh orang perorangan atau badan usaha yang bukan merupakan anak perusahaan atau bukan cabang perusahaan yang dimiliki, dikuasai, atau menjadi bagian baik langsung maupun tidak langsung dari usaha menengah atau usaha besar yang memiliki kekayaan bersih lebih dari Rp 50.000.000 sampai dengan paling banyak Rp 500.000.000 tidak termasuk tanah dan bangunan tempat usaha, atau memiliki hasil penjualan tahunan lebih dari $\mathrm{Rp}$ 300.000.000 sampai dengna paling banyak Rp 2.500.000.000.

c. Usaha menengah merupakan usaha ekonomi produktif yang berdiri sendiri, yang dilakukan oleh orang perorangan atau badan usaha yang bukan merupakan anak perusahaan atau cabang perusahaan yang dimiliki, dikuasai, atau menjadi bagian baik langsung maupun tidak langsung dengan usaha kecil atau usaha besar dengan jumlah kekayaan bersih atau hasil penjualan tahunan sebagaimana diatur dalam undang-undang.

Perkembangan bisnis online pada UMKM meningkat sebanyak 3,79 juta usaha dari jumlah total pelaku UMKM yang ada di Indonesia (Ayu Yuliani, 2017). 
Peningkatan usaha berbasis online ini tentunya didukung oleh pemerintah dengan mengadakan program "8 Juta UMKM Go Online". Kegiatan ini diharapkan dapat mempercepat transformasi UMKM di Indonesia dengan penggunaan teknologi digital. Oleh karena itu maka dianggap perlu melakukan pengembangan digitalisasi marketing dalam melakukan pengelolaan bisnis sebagai upaya dalam mengahadapi persaingan secara global.

Kabupaten Karawang yang memiliki 30 kecamatan dengan jumlah penduduknya mencapai 2.336.009 jiwa (BPS, 2019) merupakan salah satu daerah dengan kawasan industri terbesar di Indonesia. Hal ini tentunya menjadi sebuah peluang bagi pelaku usaha, salah satunya pelaku usaha di Desa Wanakerta, Kecamatan Teluk Jambe Barat. Kecamatan Teluk Jambe Barat memiliki jumlah penduduk sebesar 53.576 jiwa pada tahun 2018 (BPS, 2019), dimana Desa Wanakerta memiliki 10\% dari jumlah penduduk Kecamatan Teluk Jambe Barat yaitu sebesar 5.369 jiwa yang mayoritas pekerjaanya adalah buruh tani, petani dan pedagang/pelaku usaha.

Desa Wanakerta memiliki UMKM yang dikembangkan oleh masyarakat sendiri yaitu usaha ukiran pahat yang bernama "Martini Art". Dengan adanya potensi desa seperti lokasi desa yang strategis dan dekat dengan pusat keramaian kota Karawang menjadi peluang tersendiri dalam proses pengembangan UMKM, sehingga masyarakat Desa Wanakerta memiliki peluang kehidupan yang lebih baik dan maju di sektor ekonomi, kemudian Sumber Daya Manusia (SDM) yang banyak, serta kesenian khas desa. Hal ini seyogyanya dapat dimanfaatkan secara maksimal oleh desa untuk meningkatkan penjualan UMKM Martini Art, namun masih terkendala dengan kurangnya promosi yang dilakukan oleh pemilik maupun oleh pemerintah setempat, terutama minimnya promosi di media sosial ataupun digital marketing.

Berdasarkan dengan permasalahan yang terjadi di Desa Wanakerta, maka perlu dilakukan Pengabdian Pada Masyarakat berkaitan dengan sosialisasi digital marketing untuk UMKM Martini Art. Namun dengan adanya kondisi saat ini dimana masih diterapkannya social distancing dan larangan untuk mengumpulkan 
banyak orang, maka pengabdian ini ditujukan kepada pejabat wilayah setempat dengan tujuan:

a. Menyampaikan edukasi mengenai kebutuhan digital marketing kepada UMKM Martini Art bahkan ke seluruh masyarakat Desa Wanakerta

b. Menerapkan dan mengawasi digital marketing di UMKM Martini Art Desa Wanakerta agar promosinya dapat menjangkau target pasar secara luas, tepat dan relevan, baik bagi masyarakat Karawang, tingkat nasional maupun tingkat internasional.

\section{METODE}

Program kegiatan pengabdian pada masyarakat ini berupa sosialisasi kebutuhan digital marketing pada UMKM Martini Art di Desa Wanakerta. Sosialisasi dilakukan kepada pejabat desa yaitu Kepala Desa dan Sekretaris Desa Wanakerta dengan menggunakan metode:

1. Metode Ceramah

Pemaparan hasil wawancara dengan UMKM Martini Art bahwa UMKM tersebut membutuhkan alat promosi yang efektif sesuai kebutuhan di jaman sekarang, terlebih saat kondisi pandemic.

2. Metode Diskusi

Mempresentasikan beberapa e-marketing yang telah disiapkan untuk membantu promosi UMKM Martini Art secara digital

3. Metode Simulasi

Memberi kesempatan kepada Kepala Desa dan Sekretasris Desa untuk mempraktikan e-marketing yang sudah disiapkan. Kemudian membantu memilih digital marketing yang paling efektif bagi UMKM Martini Art maupun UMKM lain di wilayah Desa Wanakerta

Dengan adanya pendekatan yang dilakukan terhadap pemilihan digital marketing, diharapkan pejabat wilayah setempat bisa ikut memajukan, meningkatkan dan mengawasi keberlangsungan e-marketing tersebut sehingga mengangkat perekonomian masyarakat. 


\section{HASIL DAN PEMBAHASAN}

Pengabdian kepada masyarakat dengan judul kegiatan "Sosialisasi Kebutuhan Digital Marketing (Konsep untuk UMKM Martini Art Desa Wanakerta)" ini dilaksanakan pada hari Selasa, 01 September 2020 di Kantor Desa Wanakerta, Kecamatan Teluk Jambe Barat. Kegiatan ini dihadiri oleh Kepala Desa Wanakerta dan Sekretaris Desa Wanakerta, dimana kegiatan sosialisasi berjalan dengan baik dan lancar sesuai dengan yang diharapkan. Peserta terlihat antusias dan aktif dengan materi yang diberikan.

Desa Wanakerta memiliki berbagai macam UMKM (Usaha Mikro Kecil Menengah) salah satunya UMKM milik Pak Marto yaitu Seni Pahat Kayu yang berdiri sejak tahun 2014, awalnya Pak Marto memiliki tim dalam usahanya, namun seiring berjalannya waktu, pada akhirnya Pak Marto yang melanjutkan usaha yang ia bangun dengan seorang diri. Dari segi peralatan yang ia pakai, sangatlah minim yang dimana peralatan yang ia miliki yaitu peralatan seadanya. Untuk tingkat kesulitan tak sebanding dengan harga yang ia jual terhadap hasil Seni Pahat Kayunya. Alhasil Pak Marto menjual Seni Pahat Kayunya dari mulai Rp 100.000 sampai Rp. 15.000.000. Ditambah lagi dengan kondisi pandemi seperti ini, makin membuat omset penjualannya semakin menurun.

Karya yang dihasilkan dari Pak Marto ini sangatlah unik, yaitu berupa patung kayu, hiasan dinding (kaligrafi, kepala domba, serabut akar, lukisan). Tak hanya itu produk yang dihasilkan juga ada berupa peralatan rumah tangga seperti meja dan kursi maupun asbak yang dengan kualitas kayu yang baik.
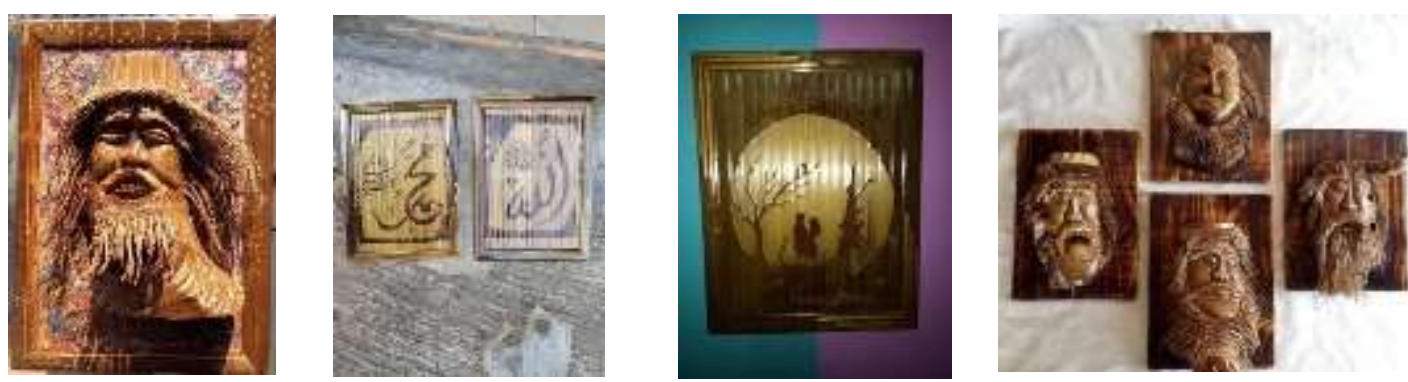

Gambar 1. Produk Ukir UMKM Martini Art 
Berdasarkan dari kegiatan sosialisasi ini, didapatkan hasil yaitu:

1. Kebudayaan dan kesenian di Desa Wanakerta masih berjalan walaupun di tengah keterbatasan. Masyarakat menganggap kesenian dan kebudayaan daerah mereka sebagai modal dasar pembangunan yang bisa saja menjadi acuan pembangunan selanjutnya, juga sebagai warisan budaya yang bernilai luhur dimana diharapkan dapat menjadi pengembangan pariwisata budaya. Di bidang pariwisata, sebenarnya Desa Wanakerta tidak memiliki tempat wisata yang dapat diandalkan, namun masyarakat berharap bahwa UMKM Martini Art yang merupakan pahatan kayu khas Wanakerta dapat menjadi kesenian, kebudayaan dan tempat produksinya suatu saat bisa dibuka menjadi pariwisata bagi masyarakat luas. Sehingga kekayaan khas Wanakerta tidak hilang dan dapat dilestarikan.

2. Jaringan telekomunikasi sudah berkembang di Desa Wanakerta sejak tahun 2000-an, seperti jaringan telkomsel, indosat, XL bahkan jaringan internet pun sudah bisa digunakan dengan lancar. Akan tetapi pemanfaatan jaringan internet dirasa masih kurang maksimal. Internet baru sebatas untuk komunikasi atau media social bagi anak remaja saja.

3. Beberapa digital marketing untuk mempromosikan dan melakukan penjualan produk UMKM Martini Art di Desa Wanakerta:

- Facebook Martini Art

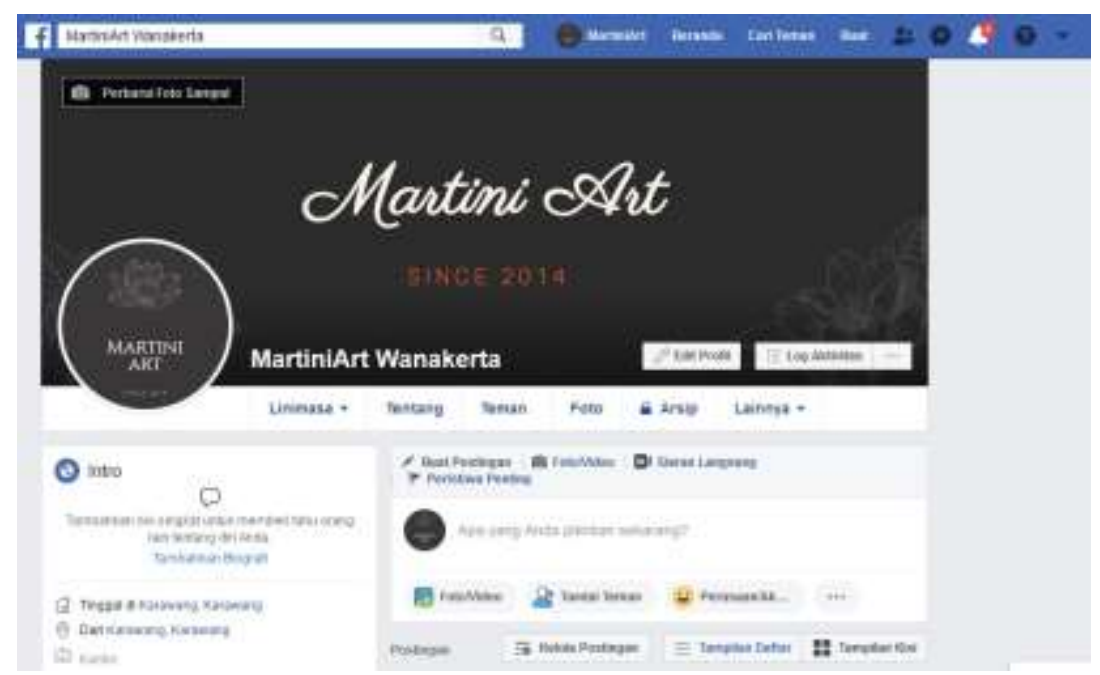

Gambar 2. Platform Facebook untuk UMKM Martini Art 
Syifa Pramudita Faddila ${ }^{1}$, Doni Efendi ${ }^{2}$, Siti Arinka Dwi Sulistia $^{3}$, Muhammad Farhan Reza Pahlevi ${ }^{4}$

Vol. 3 No 2, Agustus 2021

ISSN 2657-0203

e-ISSN 2686-0244

- Instagram Martini Art

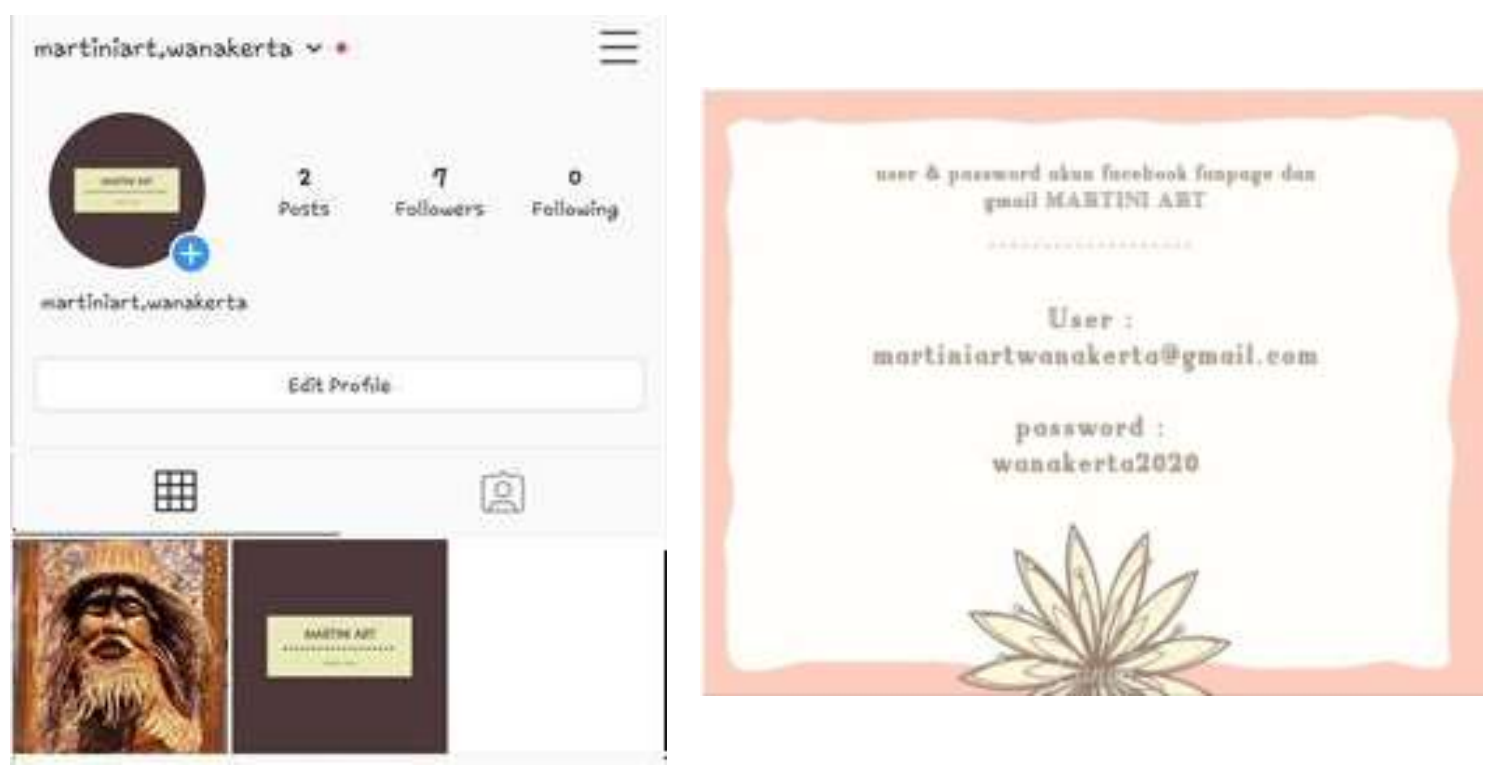

Gambar 3. Platform Instagran untuk UMKM Martini Art

- Perencanaan Penjualan Seni Ukir Martini Art Berbasis Web

a. Tampilan Halaman Login

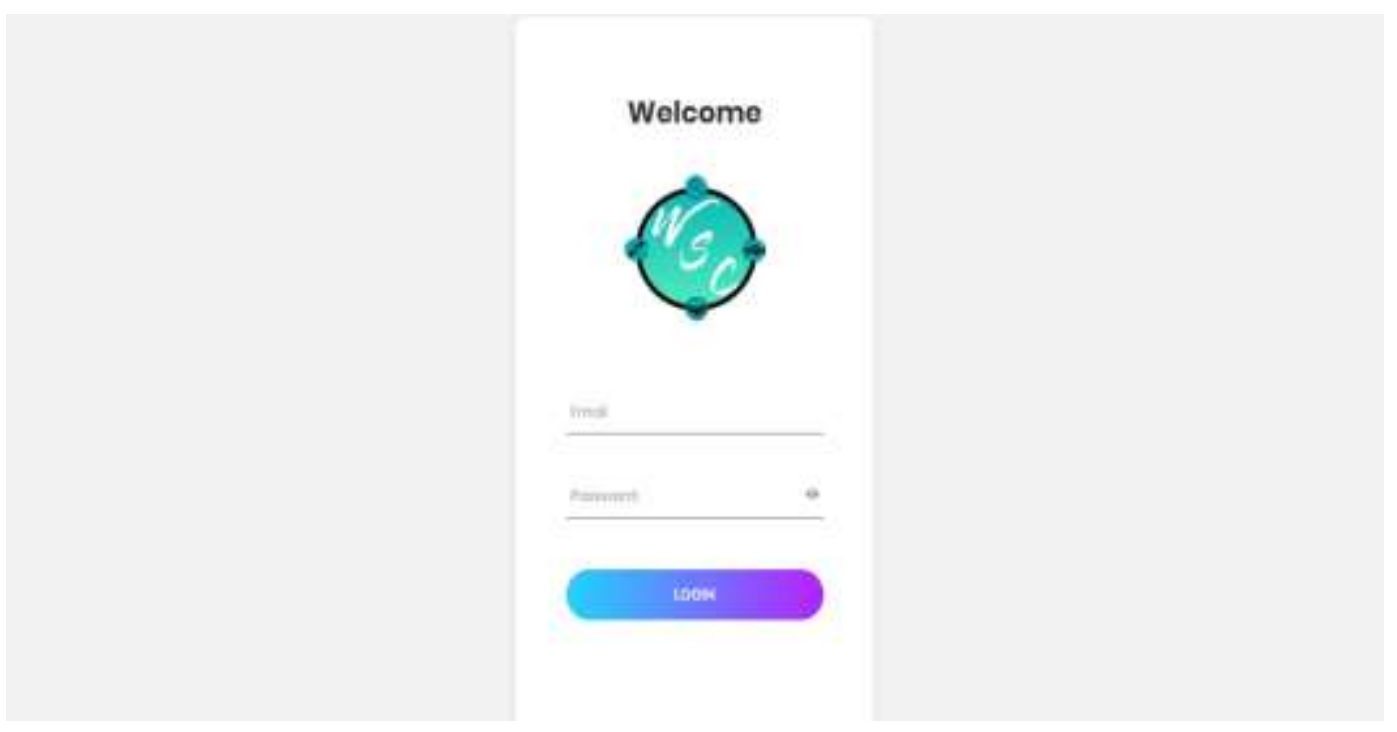

Gambar 4. Tampilan Halaman Login Web 
Syifa Pramudita Faddila ${ }^{1}$, Doni Efendi ${ }^{2}$, Siti Arinka Dwi

Sulistia $^{3}$, Muhammad Farhan Reza Pahlevi ${ }^{4}$

Vol. 3 No 2, Agustus 2021

ISSN 2657-0203

e-ISSN 2686-0244

b. Tampilan Menu Halaman Utama

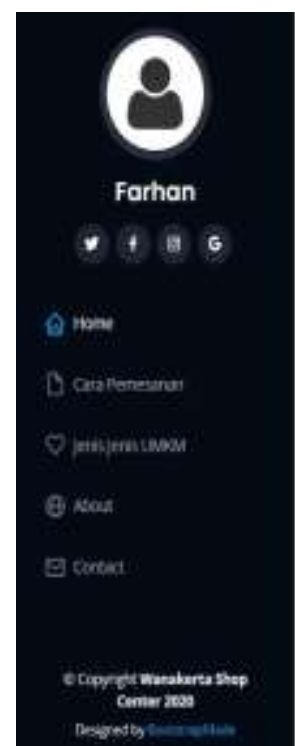

\section{Cara Pemesanan}

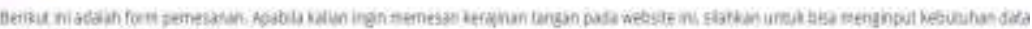
permberan pang ada dhamer in.

Gambar 5. Tampilan Menu Halaman Utama Web

c. Tampilan Cara Pemesanan

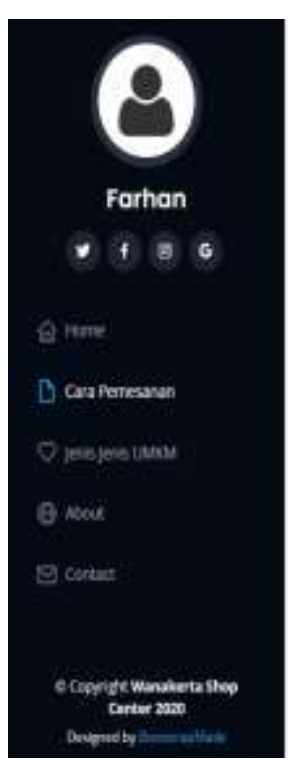

\section{Cara Pemesanan}

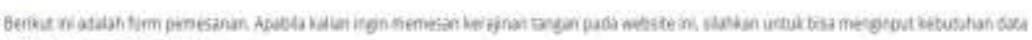
penterishyarzada abamahiai
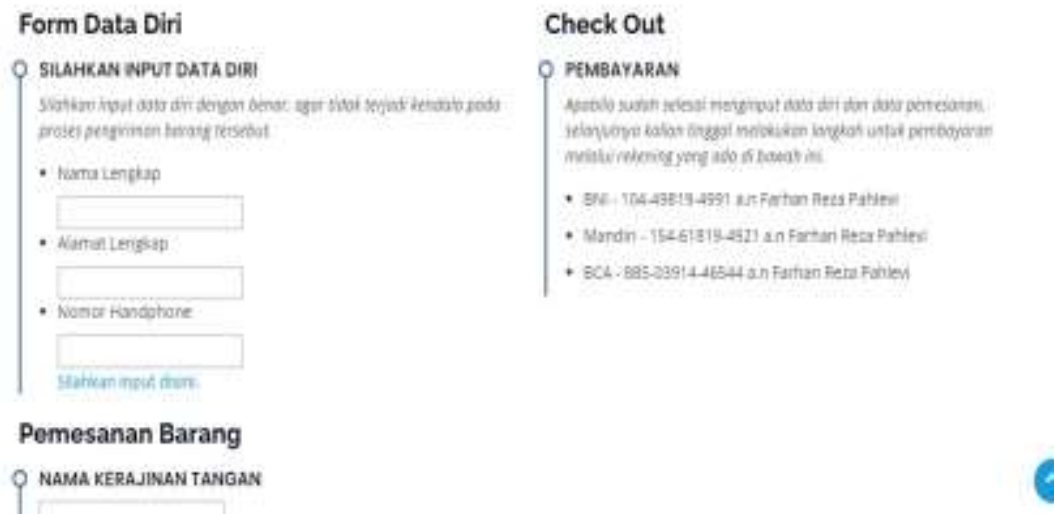

Gambar 6. Tampilan Cara Pemesanan di Web 
d. Tampilan Form Input Data Diri

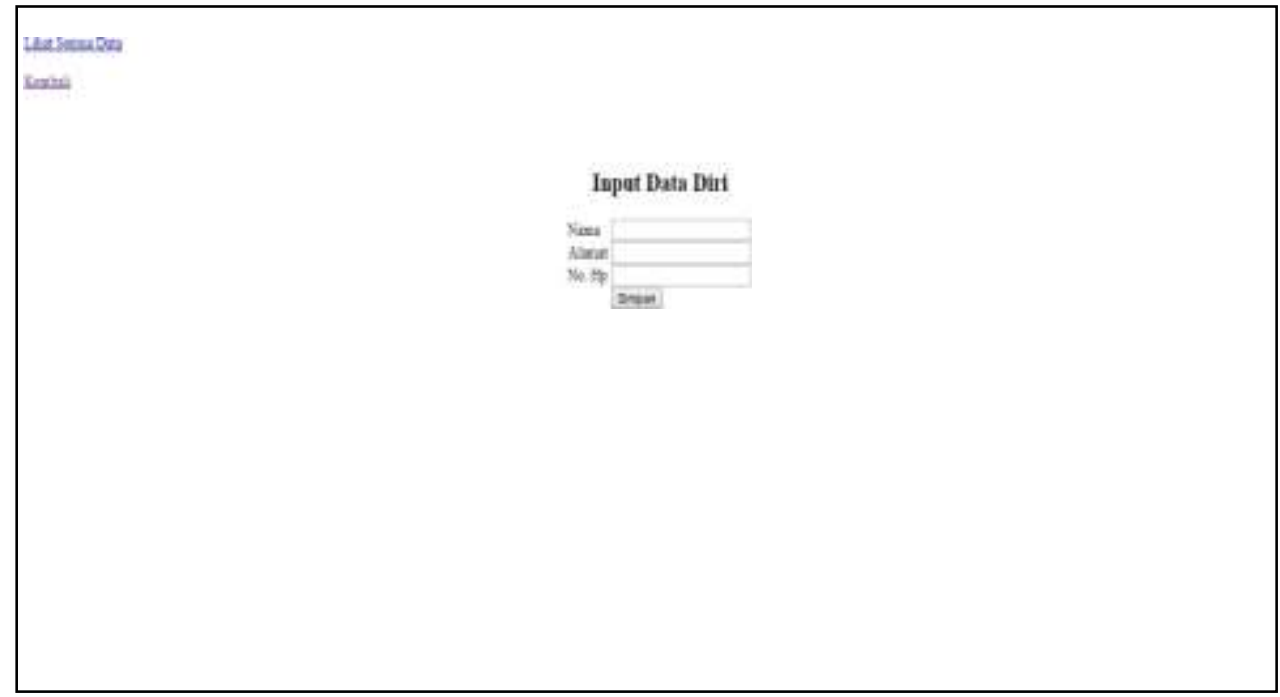

Gambar 7. Tampilan Form Input Data Diri di Web

e. Tampilan Form Input Data Seni Ukir

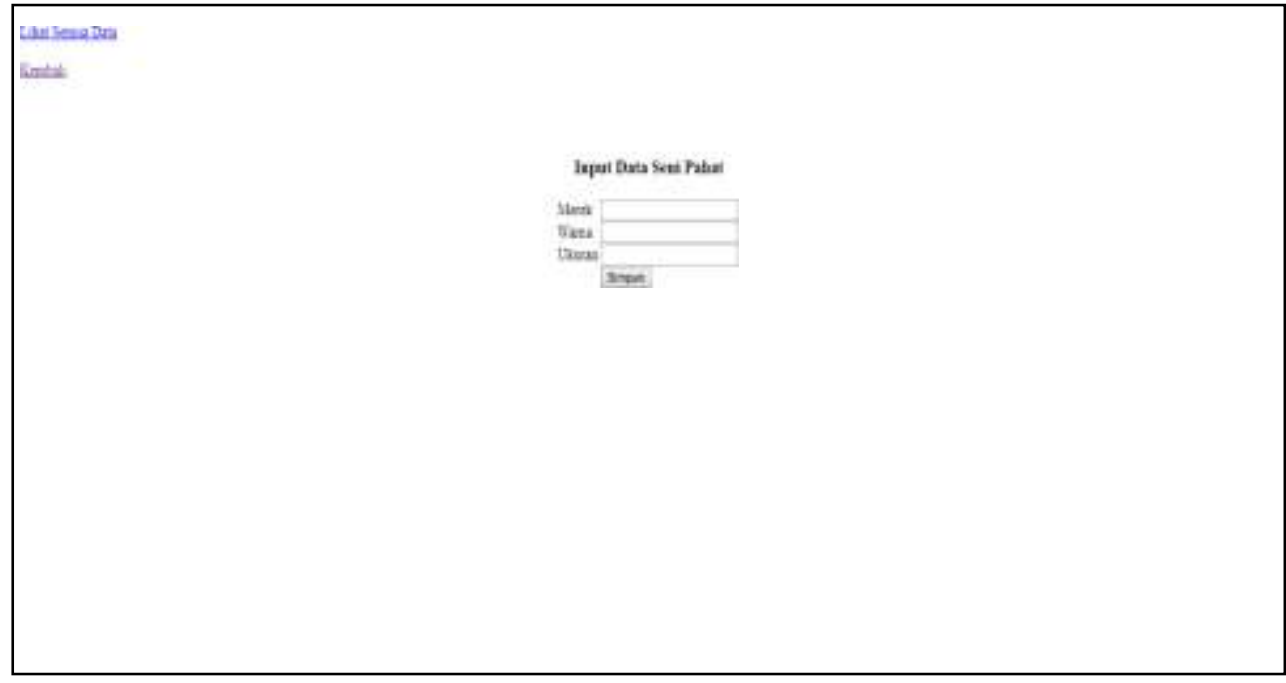

Gambar 8. Tampilan Form Input Data Seni Ukir di Web

4. Setelah memberi kesempatan kepada Kepala Desa dan Sekretasris Desa untuk mempraktikan e-marketing yang telah dipresentasikan dan dilakukan diskusi, maka semua e-marketing akan digunakan oleh Desa Wanakerta guna menunjang perkembangan usaha Martini Art dan menjadi acuan dasar bagi UMKM yang lain. 


\section{KESIMPULAN DAN SARAN}

Berdasarkan hasil pelaksanaan kegiatan sosialisai kebutuhan digital marketing pada UMKM Martini Art, maka berikut beberapa kesimpulan yang dapat diambil:

1. Kebutuhan UMKM Martini Art dalam digital marketing sudah terpenuhi dengan dipilihnya platform Facebook, Instagram dan Web oleh Kepala Desa dan Sekretaris Desa Wanakerta.

2. Kepala Desa dan Sekretaris Desa bersedia untuk melakukan edukasi emarketing yang telah di pilih kepada UMKM Martini Art maupun ke seleruh UMKM yang ada di Desa Wanakerta. Kemudian bersedia juga untuk melakukan pemantauan terhadap penggunaan digital marketing tersebut.

Saran dari hasil kegiatan pengabdian kepada masyarakat ini yaitu:

1. Melakukan evaluasi terhadap penggunaan digital marketing pada UMKM Martini Art, baik dari segi teknologi maupun dampak ekonominya.

2. Mengembangkan platform web Martini Art dengan fitur-fitur yang lebih menarik.

\section{DAFTAR PUSTAKA}

Ayu Yuliani. (2017). Kemenkop UKM: 3,79 Juta UMKM Sudah Go Online. Retrieved from https://www.cnnindonesia.com/ekonomi/2017111516103778-255819/kemenkop-ukm-379-juta-umkm-sudah-go-online/

Badan Pusat Statistik (BPS). 2019. Karawang dalam Angka Tahun 2019. Diunduh dari:

https://karawangkab.bps.go.id/publication/2019/08/16/33e658b7bfc07dc98a 28f9bf/kabupaten-karawang-dalam-angka-2019.html. Diakses pada 05 Desember 2019

Hamid, E.S, Susilo, Y.S, 2011, Strategi Pengembangan Usaha Mikro Kecil dan Menengah di Provinsi Daerah Istimewa Yogyakarta. Jurnal Ekonomi Pembangunan, Vol 12, No 1, Juni 2011 Halaman 45-55 
Syifa Pramudita Faddila ${ }^{1}$, Doni Efendi ${ }^{2}$, Siti Arinka Dwi Sulistia $^{3}$, Muhammad Farhan Reza Pahlevi ${ }^{4}$ Vol. 3 No 2, Agustus 2021

ISSN 2657-0203 e-ISSN 2686-0244

Undang-Undang Republik Indonesia No.20 Tahun 2008 tentang Usaha Mikro, Kecil dan Menengah 